\title{
The Effects of Pulsed UV Light Implementation on the Preservation Duration of Şavak Cheese Made from Raw Milk
}

\author{
Betül Yücel ${ }^{1, a, *}$, Özlem Pelin Canº \\ ${ }^{1}$ Sivas Cumhuriyet University Institute of Science, 58140 Sivas, Turkey \\ ${ }^{2}$ Sivas Cumhuriyet University Faculty of Engineering, Department of Food Engineering, 58140 Sivas, Turkey
}

${ }^{*}$ Corresponding author

\begin{tabular}{l|l}
\hline A R T I C LE IN F O & A B S T R A C T \\
\hline Research Article & $\begin{array}{l}\text { This study aimed to investigate the effect of pulsed UV light on the the preservation of the Şavak } \\
\text { cheese. In this study, the samples of Savak cheese (average } 2 \mathrm{~cm} \text { ) that were produced from raw milk } \\
\text { were exposed to two-sided pulsed UV light. The microbial analysis (enterobacteria, psychrophilic } \\
\text { aerob, lactic acid, sulphate reducing bacteria, S.aureus and yeast-fungus) and chemical analysis } \\
\text { (acidity, pH and the number of thiobarbituric acid) of şavak cheese were performed during storage } \\
\text { time }\left(25 \text { days) at } 4{ }^{\circ} \mathrm{C} \text {. According to the results, spoilage was observed in the control group after ten }\right. \\
\text { days, Group } 1 \text { was the best in terms of microbiological quality. When experimental samples were } \\
\text { compared to the control group, no statistically differences were observed in terms of TBA, acidity, } \\
\text { and pH value. }\end{array}$ \\
Accepted : $08 / 10 / 2021$
\end{tabular}

Keywords:

Pulsed UV light

Savak cheese

Raw milk

Decontamination

Shelf life A B S T R A C T

and $\mathrm{pH}$ value.

Türk Tarım - Gıda Bilim ve Teknoloji Dergisi, ?(?): 9(12): 2246-2252, 2021

\section{Çiğ Sütten Yapılan Şavak Peynirinde Atımlı Işık Uygulamalarının Muhafaza Süresi Üzerine Etkisi}

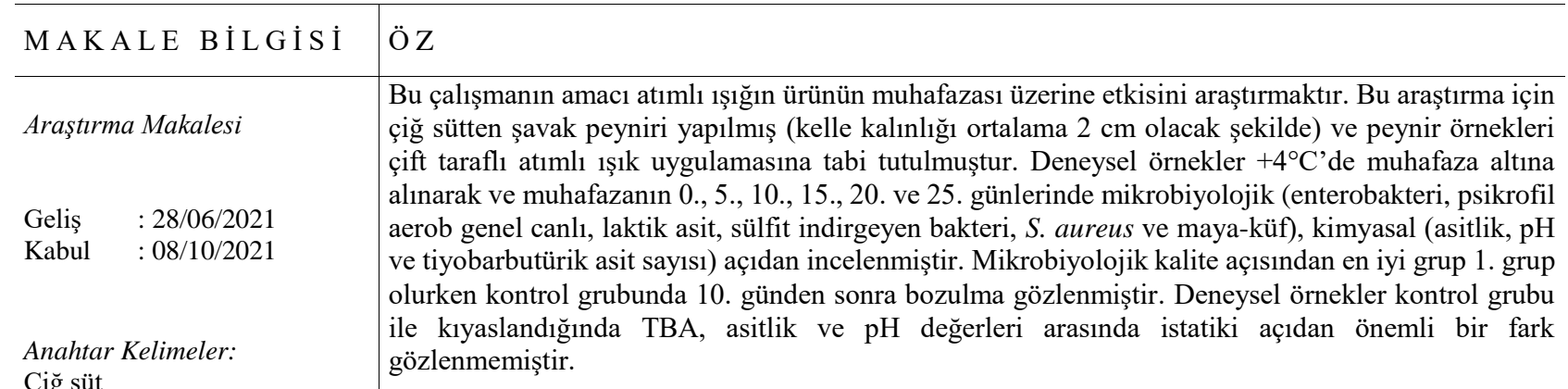

Şavak peyniri

Atımlı UV

Dekontaminasyon

Raf ömrü 


\section{Introduction}

The presence of pathogenic microorganisms in milk and cheese in a dairy product such as cheese, which is highly consumed, poses a danger to public health in terms of food safety and is not desired in these products. Pathogenic microorganisms are a big threat to public health. Spoilage microorganisms that can be found in cheese affect the taste, smell, appearance and structure of the food and the shelf life of the product (Weimer, 2001).

An increasing interest in the preservation methods has been observed in food industry to overcome the economic losses resulting from microbiological spoilage, and to minimize foodborne diseases (Galvez et al. 2008). In the dairy industry, thermal methods are generally preferred to extend the shelf life of the product and ensure its reliability (Trujillo et al. 2002). In addition to traditional practices (thermal method, salt preservation, acidification, drying and chemical preservation) used to preserve dairy products, new methods have been developed to improve product quality (Ross et al. 2003). These methods mainly aim at extending the shelf life of milk and its products and inactivating pathogenic microorganisms. Moreover, these new methods are much easy to apply and they preserve the nutritional value and sensory properties of milk and products (Devlieghere et al. 2004, Tülek and Filizay 2006).

Milk is an ideal environment for the growth of microorganisms. It is especially important for products that can be stored for a long time, such as cheese, which are processed raw or subsequently contaminated even if thermal-treated. The obligation to keep the cheese produced by traditional methods in brine for 3 months is stated in the Turkish Food Codex. Compliance with this period is necessary to establish food safety. However, consuming Savak cheese earlier than completion of the brine period is very common in public. This situation results in quick deterioration of the savak cheese and affects public health adversely. This period not only negatively affects the sensory properties of cheese, but also causes economic losses.

Pulsed Light (PL) application is a non-thermal technology that provides an antimicrobial effect without damaging the nutritional values, chemical properties and surface of the food applied with ionized light. This method is also approved by the FDA (Food and Drug Administration) in foods (Brown 2007). In PL process, Broad spectrum wavelengths $(200-1000 \mathrm{~nm})$ in the UV region close to the light source are applied (Wekhof, 2000; Gómez-López et al., 2005; Elmnasser et al., 2010, OmsOliu et al. 2010). At least 1 pulsed light with an energy density of approximately $0.01-50 \mathrm{~J} / \mathrm{cm} 2$ is applied to the part to be treated. In this application, wavelengths varying in the range of 170-2600 nm should be used. One-twenty flashes are applied per second, varying the duration of the pulses between $1 \mu \mathrm{s}$ and $0.1 \mathrm{~s}$ (Barbosa-Canovas et al., 1998). PL application creates a broad antimicrobial effect on pathogenic microorganisms in foods (Rowan et al., 1999; Gómez-López et al., 2005; Lasagabaster et al., 2011; Fernández et al., 2012; Artíguez et al., 2012). Present investigation aimed to prolong the shelf life of Şavak cheese against antimicrobiological activity by using pulsed UV light quality.

\section{Material and Method}

\section{Preparation of Savak Cheese Samples}

The milk to be used in the production of Şavak cheese was obtained from a local dairy and kept in the laboratory at $+4{ }^{\circ} \mathrm{C}$ until the experimental samples were prepared. Liquid rennet (REN-NA) containing $100 \%$ chymosin was used for cheese development. A $40 \%$ (w/v) solution of $\mathrm{CaCl} 2$ was added to the raw milk used in the production of Şavak cheese, on a $20 \mathrm{~g}$ basis to $100 \mathrm{~L}$ milk. After production, Savak cheese was packaged aerobically and stored at $+4^{\circ} \mathrm{C}$.

\section{Pulsed UV Device}

The Steri-Pulse XL®3000 Pulsed UV light system (LH840, XENON Corporation, Wilmington, USA) was used for the inactivation. The xenon lamp was adjusted to make 3 pulses per second. The duration of each pulse was maintained $360 \mu \mathrm{s}$. The system emits $1.27 \mathrm{~J} / \mathrm{cm}^{2}$ of light energy per pulse, $1.5 \mathrm{~cm}$ below the lamp surface, with a $3800 \mathrm{~V}$ input. The distance between the lamp and the quartz glass is $5.8 \mathrm{~cm}$.

\section{Savak Cheese Production and Preparation of Experimental Groups}

Firstly, the raw milk was heated to fermentation temperature $\left(38-40^{\circ} \mathrm{C}\right)$, and yeast and $\mathrm{CaCl} 2$ were added, and then left for 30 minutes. After the clot was cut off, cheese was strained and kept under pressure for 16 hours. At the end of the pressure period, the cheese samples were cut to $10 \times 10 \times 10$ size and experimental groups were formed. Experimental groups were listed. The control group was not exposed to pulsed UV light. 1st group at a distance of $5 \mathrm{~cm}$ from the UV lamp for 60 seconds, 2nd group: 30 seconds at a distance of $5 \mathrm{~cm}$ from the UV lamp, 3rd group was $8 \mathrm{~cm}$ away from the UV lamp for 60 seconds, 4th group: 30 seconds at a distance of $8 \mathrm{~cm}$ from the UV lamp, the 5 th group was $13 \mathrm{~cm}$ away from the UV lamp for 60 seconds, the 6th group was composed of the savak cheese samples exposed to pulsed light for 30 seconds at a distance of $13 \mathrm{~cm}$ from the UV lamp.

\section{Pulsed UV Application and Temperature-Energy Measurements}

Savak cheese samples (except $\mathrm{C}$ group) were placed in the cabinet $(0.64 \mathrm{~m} \times 0.15 \mathrm{~m} \times 0.19 \mathrm{~m})$ and they were applied UV pulsed light on both sides at 3 different shelf distances $(5,8$ and $13 \mathrm{~cm})$ and in 2 different durations (30 and 60 seconds). In the pulsed UV light application, the process lasting 60 seconds at $5 \mathrm{~cm}$ was defined as "severe", the process lasting 30 seconds at $8 \mathrm{~cm}$ was defined "moderate" and the process lasting 30 seconds at $13 \mathrm{~cm}$ was defined as "light". Temperature and energy measurements were made for $5 \mathrm{~cm}-60 \mathrm{~s}$ (severe), $8 \mathrm{~cm}-30$ $\mathrm{s}$ (moderate) and $13 \mathrm{~cm}-30 \mathrm{~s}$ (light) steps. Temperature changes during the application were measured using an infrared thermometer (Extech Instrument, USA). The measurement was made by keeping the thermometer 2-3 $\mathrm{mm}$ away from the surface of the cheese samples, before and immediately after the process, and temperature changes were examined. 


\section{Chemical Analysis on Experimental Samples}

Chemical analyses were performed at $0,5,10,15,20$ and for 25 days. The $\mathrm{pH}$ values of the samples were measured using a $\mathrm{pH}$ meter (HANNA 221) measuring in the water phase at $25 \pm 1{ }^{\circ} \mathrm{C}$. (Marshall 1992). Titratable acidity values were calculated according to AOAC (1997) standard. The thiobarbituric acid (TBA) method described by King (1962) was modified and used to determine the extent of lipid oxidation during pulsed UV treatment. In brief, $10 \mathrm{~g}$ cheese sample was homogenized for 3 minutes by adding $25 \mathrm{ml}$ of water. After, the mixture was heated to $30^{\circ} \mathrm{C}$ in a water bath, $1 \mathrm{ml}$ of TCA $(1 \mathrm{~g} / 1 \mathrm{~mL})$ and $2 \mathrm{ml}$ of $95 \%$ ethanol were added and homogenized again for $10 \mathrm{~s}$. Then the mixture was passed through filter paper and placed in a test tube. After adding $1 \mathrm{ml}$ of $1.4 \%$ TBA solution (prepared in $95 \%$ ethanol) to it, the tubes were mixed with vortex and incubated at $60^{\circ} \mathrm{C}$ for 1 hour. The absorbance values read at $532 \mathrm{~nm}$ were read against the standard blank solution on a Genesys 10S-UV VIS brand spectrophotometer. TBA number was defined by multiplying the obtained absorbance value by 7.8 .

\section{Microbiological Analysis on Experimental Samples}

For coliform analysis, samples (raw milk and savak cheese) were grown VRB agar (LABM, Lancashire, UK) and incubated for 24 hours at $35^{\circ} \mathrm{C}$ after pouring a double layer of agar (Pichhardt, 2004). For Psychrophilic Aerobic Bacteria count, samples were cultivated with Plate Count Agar (PCA) (LABM, Lancashire, UK) plate casting technique and incubated at $7^{\circ} \mathrm{C}$ for 7 days (Rogga et al., 2005). Potato Dextrose Agar (Oxoid CM 139), pH adjusted to 3.5 using $10 \%$ tartaric acid, was used as the medium for yeast and mold enumeration and incubated at $22 \pm 1^{\circ} \mathrm{C}$ for 5 days. Colonies formed at the end of all these processes were counted (Marshall 1992, Harrigan 1998). In order to enumerate lactic acid bacteria in experimental samples, Planting was done using Man Rogosa Sharpe Agar for Lactobacillus spp. and M17 Agar for Lactobacillus spp. from the appropriate dilution with the pour plate method and incubated at $37^{\circ} \mathrm{C}$ for 48 hours under anaerobic conditions (Swanson ve ark, 1992). For Staphylococcus aureus enumeration, experimental samples were inoculated on Baird Parker Agar (BPA) (Oxoid CM 275) containing 50 $\mathrm{ml} / \mathrm{l}$ lt Egg Yolk Tellurite Emulsion (Oxoid SR 54) and incubated at $37^{\circ} \mathrm{C}$ for 48 hours (FAO, 1992). Coagulase (Oxoid Staphytect Plus 650) test was applied by taking 1-3 samples from suspicious typical-atypical colonies growing in BPA (Bridson, 1998). Detection and enumeration of sulfide-reducing anaerobic bacteria were carried out using the ISO 15283 (2003) method. Iron Sulfite Agar (Scharlau) was incubated on the medium by double-layer cast plate method at $37^{\circ} \mathrm{C}$ for 48 hours under anaerobic conditions. At the end of the incubation period, black colored colonies with a black zone around them were counted as sulfide-reducing anaerobic bacteria (Harrigan 1998).

\section{Statistical Analysis}

Data analysis was performed using the Statistical Analysis System (SAS) (Version 6.1, USD) package program. By comparing the inter-group and intra-group inter-day values, the data were subjected to analysis of variance in terms of fixed effects and interactions between variables, in accordance with a $3 \times 3 \times 2$ factorial design, as "Savak cheese amount $x$ number of recurrences $\times$ number of samples". Fisher's least squares (LSD) test was used according to the General Linear Models (GLM) procedure. The standard deviation values of all means were calculated (Statistical Analysis System (SAS)) (SAS, 1998).

\section{Results and Discussion}

\section{Analysis Findings of Raw Milk}

Platform tests of the supplied raw milk were performed and it resulted in no antibiotics and inhibitory substances. The microbiological findings of the analysis of raw milk are provided in Table 1 and the chemical analysis findings are provided in Table 2.a.

Table 1. Microbiological Analysis Findings of Raw Milk $(\log \mathrm{cfu} / \mathrm{ml})$

\begin{tabular}{l|c}
\hline \multicolumn{1}{c|}{ Microorganism } & Findings \\
\hline Sufit Reducing Anaerobe & Not examined \\
Lactic Acid Bacteria & Not examined \\
Psychrophilic General Living Organism & 6.06 \\
Enterobacteria & 4.31 \\
Stafilococcus aureus & 1.2 \\
Yeast-mold & 3.89 \\
\hline
\end{tabular}

Table 2.a. Chemical Analysis Findings of Raw Milk

\begin{tabular}{l|c}
\hline \multicolumn{1}{c|}{ Chemicals } & Findings \\
\hline $\mathrm{pH}$ & 6,62 \\
Acidity (\% lactic acid) & 0,148 \\
TBA & Not Available \\
\hline
\end{tabular}

Table 2.b. Chemical findings of cheese

\begin{tabular}{l|c}
\hline \multicolumn{1}{c|}{ Chemicals } & Findings \\
\hline dry matter $(\mathrm{g} / 100 \mathrm{~g})$ & 46.94 \\
Fat & 22.78 \\
$\mathrm{pH}$ & 5.8 \\
Total acidity & 0.98 \\
\hline
\end{tabular}

Table 3. Energy amounts varying depending on the distance from the quartz lamp

\begin{tabular}{c|c}
\hline Distance $(\mathrm{cm})$ & Released Energy $\left(\mathrm{J} \cdot \mathrm{cm}^{-2} \cdot \mathrm{s}^{-1}\right)$ \\
\hline 5 & $1.69 \pm 0.07$ \\
8 & $1.14 \pm 0.05$ \\
13 & $0.80 \pm 0.00$ \\
\hline
\end{tabular}

\section{Temperature and Energy Levels in Pulsed UV Light} Application

Temperature changes in samples are important to determine the usability of pulsed UV light on Şavak cheese. The initial temperature of the savak cheese used in the measurement was $4 \pm 0.4^{\circ} \mathrm{C}$. At $13 \mathrm{~cm}-30 \mathrm{~s}$ (mild), $8 \mathrm{~cm}-$ $30 \mathrm{~s}$ (moderate) and $5 \mathrm{~cm}-60 \mathrm{~s}$ (severe) applications, there was an increase of $6.02 \pm 0.5^{\circ} \mathrm{C}, 18 \pm 0.6^{\circ} \mathrm{C}, 31 \pm 0.3^{\circ} \mathrm{C}$ on the surface of the samples, respectively.

As a result of statistical analysis, it was determined that there was a significant difference between the applications in these three different conditions $(\mathrm{P}<0.05)$. With an average of $31^{\circ} \mathrm{C}$, the highest temperature increase occurred at the closest distance and the longest processing time $(5 \mathrm{~cm}-60 \mathrm{~s})$. Mild treatments only experienced an average temperature rise of $6.02^{\circ} \mathrm{C}$. The low temperature increase supported that pulsed UV light is a non-thermal decontamination technique (Table 3). Krishnamurthy (2006) observed $1.24 \mathrm{log}$ cfu/g reduction at $8 \mathrm{~cm} \mathrm{30s,} 1.15 \mathrm{log} \mathrm{cfu} / \mathrm{g}$ reduction at $13 \mathrm{~cm} 30 \mathrm{~s}$ in the process performed at $30 \mathrm{~s}$ at a distance of $5 \mathrm{~cm}$. 


\section{Microbiological Analysis Findings of Experimental Samples}

The Number of Yeast-Mold

The control group that was not decontaminated with pulsed UV light, was able to be analysed until the 10th day, and its results are provided in Table 4. At the end of the 10th day, yeast-mold was observed on the sample surface. For this reason, analysis of the control group could not be made in the following storage days. When comparing the control group and other groups on day 0 , the least yeastmold was observed in the $1 \mathrm{st}$ group as $2.9 \mathrm{cfu} / \mathrm{g}$. The reason for this was thought to be the closest distance to the lamp and the longest exposure to light. When we compared the groups, the difference was statistically significant $(\mathrm{P}<0.01)$, since the 1st, 3rd and 5th groups were exposed to light for a long time. Analysis was not able to be performed after the 10th day in the 2nd, 4th and 6th groups $(\mathrm{P}<0.01)$. The reason for this was thought to be the exposition of theses groups to light for less time.

In another study by Erkan (2017) using Şavak cheese, yeast and mold counts were found to be at least $2.04 \mathrm{log}$ $\mathrm{cfu} / \mathrm{g}$, at most $5.79 \mathrm{log} \mathrm{cfu} / \mathrm{g}$, and on average $5.12 \mathrm{log} \mathrm{cfu} / \mathrm{g}$ in the samples of Tulum cheese. Yildiz (2019) examined the effect of irradiation technique on the microbiological properties of cheese made from raw milk. During present study, it was applied 1, 2 and $3 \mathrm{kGy}$ as irradiation degrees. The best results ( $3 \mathrm{kGy}$ applied) were $1,2 \times 104$ at the end of the 1 st day of storage and $1,5 \times 104$ at the end of the 30th day.

\section{Number of Lactic Acid Bacteria}

The findings of lactic acid bacteria in our study are provided in Table 5. The number of lactic acid bacteria in the control group (did not receive pulsed light) was at undesirable levels after the 15th day. In addition, no significant decrease was observed in the number of lactic acid in the other groups to which pulsed light was applied $(\mathrm{P}>0.05)$. If the number of lactic acid bacteria is not sufficient, coliform bacteria and proteolytic microorganisms multiply and cause food spoilage (Kurt et al., 1991). Therefore, the number of lactic acid bacteria is desired to be high in Şavak cheese. The difference between the control group and the other groups in the experimental samples was found to be statistically significant $(\mathrm{P}<0.01)$. The change in the number of lactobacillius during ripening in white cheese made from raw milk, made by Uğur (2018), varies between 7.07 and $6.24 \mathrm{log}$ cfu/g during the ripening period on the 0 th and 30 th days.

Lactic acid bacteria are very important in the LAB food industry. Many industrially important features in LAB are encoded in plasmids expressed as extra-chromosomal genetic constructs. Plasmids do not contain the necessary genetic materials for the survival of bacteria, but they have many industrially important features. In studies, it is stated that properties such as resistance to bacteriophages, production of proteinase, metabolizing lactose, resistance to bacteriocins, heavy metals and antibiotics are encoded on plasmids.

Number of Enterobacteria

Except for the control group, in-group days were not statistically significant in other groups $(\mathrm{P}<0.01)$. The difference between the groups was statistically significant on the 10th day $(\mathrm{P}>0.01)$. This shows that the cheese samples were hygienically acceptable. A continuous increase was observed in the 2 nd and 4 th groups during the storage period. Group 2 was found to be 3.7-4.1-4.3-4.6 log $\mathrm{cfu} / \mathrm{g}$, respectively, while group 4 was 3.9-4.2-4.9 $\log$ $\mathrm{cfu} / \mathrm{g}$. The 6th group was found to be 4.1-5.1-4.9, respectively (Table 6). From these results, it was determined that the difference between cheese applications was statistically significant. $(\mathrm{P}<0.01)$. The change in the number of coliform bacteria occurring during ripening in white cheese made from raw milk by Uğur (2018) varies between 6.38 and $6.16 \log \mathrm{cfu} / \mathrm{g}$ during the ripening period on the 0th and 30th days.

\section{Number of Psychrophilic Bacteria}

The findings regarding the number of psychrophilic bacteria obtained in our study are provided in Table 7 . From day 0 th to day 25 th, the number of psychrophilic bacteria ranged from 4.0 to $7.3 \mathrm{log} \mathrm{cfu} / \mathrm{g}$. It can be observed that psychrophilic bacteria multiply during the storage of milk and dairy products in cold conditions (Parveen et al., 2016). When the control group samples were examined in terms of the number of psychrophilic bacteria, the difference between intra-group days and between groups was found to be statistically significant $(\mathrm{P}<0.01)$. Except for the control group, the difference between the within-group days was found to be insignificant $(\mathrm{P}>0.01)$ in other groups. Y1ldırım (2014) observed the number of psychrophilic aerobic bacteria as 8.25-8.17 log cfu/g between the 0th and 120th days in his study with Şavak cheese.

Number of Staphylococcus aureus

In the experimental samples of the 1st group, the number of $S$. aureus during the storage period was below the detectable level $(<1 \log \mathrm{cfu} / \mathrm{g})$. It was detected that the difference between the control group and the samples of the 2 nd, 4 th and 6 th groups was significant $(\mathrm{P}<0.01)$ on the 10th day of storage (Table 8). Coşkun and Öztürk (2000) determined an average of $5.3 \times 10^{3} \mathrm{log} \mathrm{cfu} / \mathrm{g}$ S. aureus in white cheeses collected from dairy business in Van. $S$. aureus bacteria were detected at an average level of $6.0 \times 10^{1}-1.3 \times 10^{3} \log \mathrm{cfu} / \mathrm{g}$ (Sert and Kıvanç, 1984) in white cheeses sold in Erzurum market and $5.5 \times 10^{2} \mathrm{log} \mathrm{cfu} / \mathrm{g}$ in fresh cheeses sold in Elazig (Dığrak et al. 1996).

Table 4. Yeast-mold number of experimental samples during storage (log cfu/g)

\begin{tabular}{l|ccccccc}
\hline \multirow{2}{*}{ Microorganism } & \multirow{2}{*}{ Groups } & \multicolumn{5}{c}{ Storage Periods (Day) } \\
\cline { 2 - 7 } & & 0 & 5 & 10 & 15 & 20 & 25 \\
\hline \multirow{4}{*}{ Yeast-Mold } & $\mathrm{K}$ & $3,5^{\mathrm{a}}$ & $4,5^{\mathrm{a}}$ & $4,8^{\mathrm{a}}$ & $\mathrm{NE}$ & $\mathrm{NE}$ & $\mathrm{NE}$ \\
& 1 & $2,9^{\mathrm{a}, \mathrm{y}}$ & $3,3^{\mathrm{b}, \mathrm{y}}$ & $3,7^{\mathrm{b}, \mathrm{x}}$ & 3,4 & 3,9 & 4,1 \\
& 2 & $3,5^{\mathrm{a}, \mathrm{y}}$ & $4,1^{\mathrm{b}, \mathrm{x}}$ & $4,7^{\mathrm{a}, \mathrm{x}}$ & 4,9 & $\mathrm{NE}$ & $\mathrm{NE}$ \\
& 3 & $2,7^{\mathrm{b}, \mathrm{y}}$ & $3,6^{\mathrm{b}, \mathrm{y}}$ & $3,9^{\mathrm{b}, \mathrm{y}}$ & 4,1 & 4,7 & 5,1 \\
& 4 & $3,6^{\mathrm{a}}$ & $3,9^{\mathrm{b}}$ & $4,3^{\mathrm{a}}$ & $\mathrm{NE}$ & $\mathrm{NE}$ & $\mathrm{NE}$ \\
& 5 & $3,1^{\mathrm{a}}$ & $3,5^{\mathrm{b}}$ & $3,9^{\mathrm{b}}$ & 4,3 & 3,9 & 4,3 \\
& 6 & $3,3^{\mathrm{a}, \mathrm{y}}$ & $4,8^{\mathrm{a}, \mathrm{x}}$ & $5,1^{\mathrm{a}, \mathrm{x}}$ & $\mathrm{NE}$ & $\mathrm{NE}$ & $\mathrm{NE}$ \\
\hline
\end{tabular}

$1: 5 \mathrm{~cm}-60 \mathrm{~s}, 2: 5 \mathrm{~cm}-30 \mathrm{~s}, 3: 8 \mathrm{~cm}-60 \mathrm{~s}, 4: 8 \mathrm{~cm}-30 \mathrm{~s}, 5: 13 \mathrm{~cm}-60 \mathrm{~s}, 6: 13 \mathrm{~cm}-30 \mathrm{~s}, \mathrm{x}, \mathrm{y}, \mathrm{z}$ : statistical difference between in-group days $(\mathrm{P}<0.01), \mathrm{a}, \mathrm{b}, \mathrm{c}:$ statistical difference between groups $(\mathrm{P}<0.01)$, NE: Not examined 
Table 5. Number of lactic acid bacteria during storage of experimental samples $(\log \mathrm{cfu} / \mathrm{g})$

\begin{tabular}{c|ccccccc}
\hline \multirow{2}{*}{ Microorganism } & \multirow{2}{*}{ Groups } & \multicolumn{5}{c}{ Storage Periods (Days) } \\
\cline { 2 - 7 } & & 0 & 5 & 10 & 15 & 20 & 25 \\
\hline & $\mathrm{K}$ & $5,1^{\mathrm{b}, \mathrm{y}}$ & $4,5^{\mathrm{a}}$ & $4,8^{\mathrm{a}}$ & $\mathrm{NE}$ & $\mathrm{NE}$ & $\mathrm{NE}$ \\
& 1 & $5,5^{\mathrm{b}}$ & $5,3^{\mathrm{b}}$ & $5,7^{\mathrm{b}}$ & $5,9^{\mathrm{a}}$ & 5,7 & 5,3 \\
& 2 & $6,4^{\mathrm{a}}$ & $6,6^{\mathrm{a}}$ & $6,1^{\mathrm{a}}$ & $6,7^{\mathrm{a}}$ & $\mathrm{NE}$ & $\mathrm{NE}$ \\
Lactic Acid Bacteria & 3 & $5,5^{\mathrm{b}}$ & $5,1^{\mathrm{b}}$ & $4,9^{\mathrm{b}}$ & $5,3^{\mathrm{b}}$ & 5,9 & 5,3 \\
& 4 & $6,1^{\mathrm{a}}$ & $6,7^{\mathrm{a}}$ & $6,3^{\mathrm{a}}$ & $\mathrm{NE}^{\mathrm{a}}$ & $\mathrm{NE}$ & $\mathrm{NE}$ \\
& 5 & $6,3^{\mathrm{a}}$ & $5,9^{\mathrm{b}}$ & $6,7^{\mathrm{a}}$ & $5,1^{\mathrm{b}}$ & 5,3 & 5,7 \\
& 6 & $6,5^{\mathrm{a}, \mathrm{x}}$ & $6,9^{\mathrm{a}, \mathrm{x}}$ & $5,9^{\mathrm{a}, \mathrm{y}}$ & $\mathrm{NE}$ & $\mathrm{NE}$ & $\mathrm{NE}$ \\
\hline
\end{tabular}

1: $5 \mathrm{~cm}-60 \mathrm{~s}, 2: 5 \mathrm{~cm}-30 \mathrm{~s}, 3: 8 \mathrm{~cm}-60 \mathrm{~s}, 4: 8 \mathrm{~cm}-30 \mathrm{~s}, 5: 13 \mathrm{~cm}-60 \mathrm{~s}, 6: 13 \mathrm{~cm} 30 \mathrm{~s}, \mathrm{x}, \mathrm{y}, \mathrm{z}$ : statistical difference between in-group days (P<0.01), a,b,c: statistical difference between groups $(\mathrm{P}<0.01)$, NE: not examined

Table 6. Enterobacteria count $(\log \mathrm{cfu} / \mathrm{g})$ of experimental samples during storage

\begin{tabular}{c|ccccccc}
\hline \multirow{2}{*}{ Microorganism } & \multirow{2}{*}{ Groups } & \multicolumn{5}{c}{ Storage Periods (Days) } \\
\cline { 2 - 7 } & & 0 & 5 & 10 & 15 & 20 & 25 \\
\hline \multirow{3}{*}{ Enterobacteria } & $\mathrm{K}$ & $4,1^{\mathrm{z}}$ & $5,3^{\mathrm{a}, \mathrm{y}}$ & $6,7^{\mathrm{a}, \mathrm{x}}$ & 3,4 & 3,9 & 4,1 \\
& 1 & $<1$ & $<1$ & $<1$ & $<1$ & $<1$ & $<1$ \\
& 2 & 3,7 & $4,1^{\mathrm{b}}$ & $4,3^{\mathrm{b}}$ & $4,6^{\mathrm{a}}$ & $\mathrm{NE}$ & $\mathrm{NE}$ \\
& 3 & $<1$ & $<1$ & $1,1^{\mathrm{c}}$ & $1,3^{\mathrm{b}}$ & $1,1^{\mathrm{b}}$ & $1,9^{\mathrm{b}}$ \\
& 4 & 3,9 & $4,2^{\mathrm{b}}$ & $4,9^{\mathrm{b}}$ & $\mathrm{NE}$ & $\mathrm{NE}$ & $\mathrm{NE}$ \\
& 5 & $<1$ & $<1$ & $1,9^{\mathrm{c}}$ & $2,1^{\mathrm{b}}$ & $2,7^{\mathrm{a}}$ & $2,3^{\mathrm{a}}$ \\
\hline
\end{tabular}

$1: 5 \mathrm{~cm}-60 \mathrm{~s}, 2: 5 \mathrm{~cm}-30 \mathrm{~s}, 3: 8 \mathrm{~cm}-60 \mathrm{~s}, 4: 8 \mathrm{~cm}-30 \mathrm{~s}, 5: 13 \mathrm{~cm}-60 \mathrm{~s}, 6: 13 \mathrm{~cm}-30 \mathrm{~s}, \mathrm{x}, \mathrm{y}, \mathrm{z}$ : statistical difference between in-group days (P<0.01), a,b,c: statistical difference between groups $(\mathrm{P}<0.01)$, NE: not examined

Table 7. Total psychrophilic general number of living organisms during storage of experimental samples (log cfu/g)

\begin{tabular}{l|ccccccc}
\hline \multirow{2}{*}{ Microorganism } & \multirow{2}{*}{ Groups } & \multicolumn{5}{c}{ Storage Periods (Days) } \\
\cline { 2 - 7 } & & 0 & 5 & 10 & 15 & 20 & 25 \\
\hline & $\mathrm{K}$ & $6,3^{\mathrm{a}, \mathrm{z}}$ & $7,9^{\mathrm{a}, \mathrm{x}}$ & $8,6^{\mathrm{a}, \mathrm{x}}$ & $\mathrm{NE}$ & $\mathrm{NE}$ & $\mathrm{NE}$ \\
Psychrophilic & 1 & $4,2^{\mathrm{b}, \mathrm{y}}$ & $5,1^{\mathrm{a}, \mathrm{x}}$ & $5,9^{\mathrm{c}, \mathrm{y}}$ & $6,3^{\mathrm{y}}$ & $7,1^{\mathrm{x}}$ & $7,3^{\mathrm{x}}$ \\
General Living & 2 & $5,3^{\mathrm{a}, \mathrm{y}}$ & $5,9^{\mathrm{a}, \mathrm{x}}$ & $6,3^{\mathrm{b}, \mathrm{x}}$ & $6,6^{\mathrm{x}}$ & $\mathrm{NE}^{\mathrm{y}}$ & $\mathrm{NE}$ \\
Organism & 3 & $4,1^{\mathrm{b}, \mathrm{y}}$ & $4,0^{\mathrm{c}, \mathrm{y}}$ & $5,1^{\mathrm{c}, \mathrm{y}}$ & $6,9^{\mathrm{x}}$ & $7,3^{\mathrm{x}}$ & $7,1^{\mathrm{x}}$ \\
& 4 & $5,9^{\mathrm{a}}$ & $6,3^{\mathrm{a}}$ & $6,7^{\mathrm{b}}$ & $\mathrm{NE}$ & $\mathrm{NE}^{\mathrm{a}}$ & $\mathrm{NE}$ \\
& 5 & $4,6^{\mathrm{b}, \mathrm{y}}$ & $5,1^{\mathrm{b}, \mathrm{y}}$ & $5,7^{\mathrm{c}, \mathrm{y}}$ & $6,7^{\mathrm{x}}$ & $7,1^{\mathrm{x}}$ & $7,3^{\mathrm{x}}$ \\
& 6 & $6,3^{\mathrm{a}, \mathrm{y}}$ & $7,1^{\mathrm{a}, \mathrm{y}}$ & $8,9^{\mathrm{a}, \mathrm{x}}$ & $\mathrm{NE}$ & $\mathrm{NE}$ & $\mathrm{NE}$ \\
\hline
\end{tabular}

$1: 5 \mathrm{~cm}-60 \mathrm{~s}, 2: 5 \mathrm{~cm}-30 \mathrm{~s}, 3: 8 \mathrm{~cm}-60 \mathrm{~s}, 4: 8 \mathrm{~cm}-30 \mathrm{~s}, 5: 13 \mathrm{~cm}-60 \mathrm{~s}, 6: 13 \mathrm{~cm}-30 \mathrm{~s}, \mathrm{x}, \mathrm{y}, \mathrm{z}$ : statistical difference between in-group days $(\mathrm{P}<0.01)$, a,b,c: statistical difference between groups $(\mathrm{P}<0.01)$, NE: not examined

Table 8. Staphylococcus aureus number of experimental samples during storage (log cfu/g)

\begin{tabular}{c|ccccccc}
\hline \multirow{2}{*}{ Microorganism } & \multirow{2}{*}{ Groups } & \multicolumn{5}{c}{ Storage Periods (Days) } \\
\cline { 2 - 7 } & & 0 & 5 & 10 & 15 & 20 & 25 \\
\hline \multirow{4}{*}{ Stafilococcus aureus } & $\mathrm{K}$ & 2,4 & 3,3 & $5,7^{\mathrm{a}}$ & $\mathrm{NE}$ & $\mathrm{NE}$ & $\mathrm{NE}$ \\
& 1 & $<1$ & $<1$ & $<1$ & $<1$ & $<1$ & $<1$ \\
& 2 & 2,4 & 2,4 & $2,9^{\mathrm{c}}$ & $3,1^{\mathrm{a}}$ & $\mathrm{AY}$ & $\mathrm{AY}$ \\
& 3 & $<1$ & $<1$ & $<1$ & $<1$ & 1,6 & 2,3 \\
& 5 & 2,4 & 2,6 & $4,1^{\mathrm{b}}$ & $\mathrm{NE}$ & $\mathrm{NE}$ & $\mathrm{NE}$ \\
& 5 & $<1$ & $<1$ & $<1$ & $1,7^{\mathrm{b}}$ & 2,1 & 2,9 \\
\hline
\end{tabular}

1: $5 \mathrm{~cm}-60 \mathrm{~s}, 2: 5 \mathrm{~cm}-30 \mathrm{~s}, 3: 8 \mathrm{~cm}-60 \mathrm{~s}, 4: 8 \mathrm{~cm}-30 \mathrm{~s}, 5: 13 \mathrm{~cm}-60 \mathrm{~s}, 6: 13 \mathrm{~cm}-30 \mathrm{~s}, \mathrm{x}, \mathrm{y}, \mathrm{z}:$ statistical difference between in-group days $(\mathrm{P}<0.01)$, a,b,c: statistical difference between groups $(\mathrm{P}<0.01)$, NE: not examined

\section{Chemical Analysis Findings of Experimental Samples \\ $\mathrm{pH}$ values and their change}

In our study, the change in $\mathrm{pH}$ values that occurred in the storage of Savak cheese is given in Table 9. The $\mathrm{pH}$ values of Şavak cheese samples varied between 5.27 and 5.38. The $\mathrm{pH}$ values of Şavak cheese were very close to each other from the 0th day of ripening $(\mathrm{P}>0.01)$. When the experimental samples were evaluated statistically, there was no statistical difference between the days within the group $(\mathrm{P}>0.01)$. The $\mathrm{pH}$ value of Şavak tulum cheese samples examined in the study of Erkan S. (2017) was found to be at least 4.50, maximum 6.07 and on average 5.03.
Titration acidity values and their change

The results of the analysis carried out to determine the effect of pulsed light on the \% acidity value of Şavak cheese during the storage period are given in Table 10 .

When the control group and other samples were compared with each other, it was determined that the acidity values of the cheeses were close to each other and the differences between the cheeses during the storage days were not significant $(\mathrm{P}>0.05)$.

In Aksüyek's study (2016), the acidity value of Şavak cheese made from raw cow's milk during the 60-day maturation period was found to be $0.70,1.38,1.62$ at $0-30$ 60 days, respectively. 
Table 9. Change in $\mathrm{pH}$ values of experimental samples during storage

\begin{tabular}{l|lrrccccc}
\hline & \multirow{2}{*}{ Groups } & \multicolumn{7}{c}{ Storage Periods (Days) } \\
\cline { 2 - 7 } & & 0 & & 5 & 10 & 15 & 20 & 25 \\
\hline \multirow{4}{*}{$\mathrm{pH}$} & $\mathrm{K}$ & 5.38 & 5.40 & 5.40 & 5.28 & 5.20 & 5.32 \\
& 1 & 5.26 & 5.37 & 5.27 & 5.29 & 5.21 & 5.33 \\
& 2 & 5.39 & 5.33 & 5.22 & 5.26 & 5.31 & 5.11 \\
& 3 & 5.31 & 5.49 & 5.35 & 5.31 & 5.26 & 5.13 \\
& 4 & 5.29 & 5.42 & 5.17 & 5.11 & 5.13 & 5.19 \\
& 5 & 5.26 & 5.36 & 5.25 & 5.21 & 5.26 & 5.17 \\
\hline
\end{tabular}

1: $5 \mathrm{~cm}-60 \mathrm{~s}, 2: 5 \mathrm{~cm}-30 \mathrm{~s}, 3: 8 \mathrm{~cm}-60 \mathrm{~s}, 4: 8 \mathrm{~cm}-30 \mathrm{~s}, 5: 13 \mathrm{~cm}-60 \mathrm{~s}, 6: 13 \mathrm{~cm}-30 \mathrm{~s}$.

Table 10. Change in acidity values of experimental samples during storage

\begin{tabular}{l|ccccccc}
\hline & \multirow{2}{*}{ Groups } & \multicolumn{5}{c}{ Storage Periods (Days) } \\
\cline { 3 - 7 } & & 0 & 5 & 10 & 15 & 20 & 25 \\
\hline & $\mathrm{K}$ & 1.050 & 1.080 & 1.120 & 1.130 & 1.135 & 1.138 \\
& 1 & 1.055 & 1.082 & 1.216 & 1.140 & 1.130 & 1.134 \\
Acidity & 2 & 1.060 & 1.065 & 1.075 & 1.071 & 1.077 & 1.079 \\
(\% lactic acid) & 3 & 1.120 & 1.118 & 1.113 & 1.097 & 1.095 & 1.113 \\
& 4 & 1.111 & 1.088 & 1.085 & 1.081 & 1.083 & 1.079 \\
& 5 & 1.092 & 1.094 & 1.099 & 1.112 & 1.119 & 1.207 \\
& 6 & 1.234 & 1.232 & 1.231 & 1.233 & 1.234 & 1.230 \\
\hline
\end{tabular}

1: $5 \mathrm{~cm}-60 \mathrm{~s}, 2: 5 \mathrm{~cm}-30 \mathrm{~s}, 3: 8 \mathrm{~cm}-60 \mathrm{~s}, 4: 8 \mathrm{~cm}-30 \mathrm{~s}, 5: 13 \mathrm{~cm}-60 \mathrm{~s}, 6: 13 \mathrm{~cm}-30 \mathrm{~s}$.

Table 11. Change in thiobarbuturic acid values of experimental samples during storage

\begin{tabular}{l|ccccccc}
\hline & \multirow{2}{*}{ Groups } & \multicolumn{5}{c}{ Storage Periods (Days) } \\
\cline { 2 - 7 } & & 0 & 5 & 10 & 15 & 20 & 25 \\
\hline \multirow{4}{*}{ TBA } & $\mathrm{K}$ & 0.018 & 0.015 & 0.019 & 0.018 & 0.028 & 0.035 \\
& 1 & 0.016 & 0.017 & 0.018 & 0.019 & 0.029 & 0.036 \\
& 2 & 0.030 & 0.028 & 0.027 & 0.021 & 0.022 & 0.019 \\
& 3 & 0.024 & 0.023 & 0.022 & 0.023 & 0.024 & 0.023 \\
& 4 & 0.014 & 0.016 & 0.016 & 0.017 & 0.019 & 0.021 \\
& 5 & 0.038 & 0.035 & 0.033 & 0.032 & 0.026 & 0.022 \\
& 6 & 0.016 & 0.018 & 0.018 & 0.017 & 0.019 & 0.015 \\
\hline
\end{tabular}

$1: 5 \mathrm{~cm}-60 \mathrm{~s}, 2: 5 \mathrm{~cm}-30 \mathrm{~s}, 3: 8 \mathrm{~cm}-60 \mathrm{~s}, 4: 8 \mathrm{~cm}-30 \mathrm{~s}, 5: 13 \mathrm{~cm}-60 \mathrm{~s}, 6: 13 \mathrm{~cm}-30 \mathrm{~s}$.

Thiobarbuturic acid values and change

TBA analysis results of Şavak cheeses are given in Table 11. The TBA levels of the cheeses were very close to each other from the 0th day to the 25th day of storage, and it was determined that the differences between the cheese samples were not significant $(\mathrm{P}>0.05)$. Keklik (2019) exposed the sliced pastrami samples to pulsed UV light for 5, 15, 25, 35 and $45 \mathrm{~s}$ at a distance of 5, 8 and 13 $\mathrm{cm}$. Although $5 \mathrm{~cm} / 45 \mathrm{~s}$ treatment $\left(72.3 \mathrm{~J} / \mathrm{cm}^{2}\right)$ produced a maximum reduction of $2.99 \log \mathrm{cfu} / \mathrm{cm}^{2}, \mathrm{~S}$. aureus reported that this treatment changed color, moisture, and thiobarbituric acid-reactive substances (TBARS). Can (2013) applied pulsed light on packaged and unpackaged cheeses. In his study, the difference between TBA values after exposure to light $(13 \mathrm{~cm}-5 \mathrm{~s})$, medium $(8 \mathrm{~cm}-30 \mathrm{~s})$, intense $(5 \mathrm{~cm}-40 \mathrm{~s})$ pulsed light was significant, and no significant difference was observed between the TBA values of packaged and unpackaged cheese samples.

\section{Conclusion}

Significant differences were observed between the control group and other groups in our study. Pulsed UV application does not change the sensory properties of cheese since it is not a heat treatment.
In addition, while PL application improved the microbiological quality of the product, it showed high inactivation especially on pathogenic bacteria such as $\mathrm{S}$. aureus and Enthorobacteria. Furthermore, it did not change the chemical properties of the product. Thus, it has been concluded that the application has a positive effect on the shelf life of the product and can be applied to cheese.

\section{References}

Aksüyek Hİ. 2016. Şavak tulum peyniri üretim tekniğiyle pastörize ve çiğ sütten üretilen peynirlerin olgunlaşma sürecindeki kimi niteliklerinin belirlenmesi. Yüksek Lisans Tezi, Sütçü İmam Üniversitesi, Fen Bilimleri Enstitüsü, Kahramanmaraş, Türkiye

Anonymous 2003. Microbiology of food and animal feeding stuffs-horizontal method for the enumeration of sulfitereducing bacteria growing under anaerobic conditions. ISO 15283

AOAC. 1997. Official Methods of Analysis (16th Ed.). Washington DC: Association of Official Analytical Chemists.

Artíguez ML, Arboleya, Martínez de Marañón I. 2012. Influence of $\beta$-lactoglobulin and $\beta$ - casein on Listeria innocua inactivation by pulsed light. International Journal of Food Microbiology, 153: 223-228.

Barbosa-Canovas GV, Pothakamury UR, Palou E, Swanson BG. 1998. Nonthermal preservation of food. CRC Press, New York. 
Bergdoll MS. 1989. Staphylococcus aureus. Doyle MP (Ed), Foodborne bacterial pathogens. Marcel Dekker, Inc. 463-523, New York.

Bridson EY. 1998." The Oxoid Manual" 8th Edition. Oxoid Ltd. Hamshire, pp 215-216.

Brown A. 2007. Understanding Food: principles \& preparation. Wadswort Publishing Company, United States.

Can FÖ. 2013. Decontamination of hard cheeses by pulsed UV light. The Pennsylvania State University The Graduate School Department of Agricultural and Biological Engineering (Master Thesis), USA.

Coşkun H, Öztürk B. 2000. Bazı süt işletmelerinde üretilen beyaz ve kaşar peynirlerinin mikrobiyolojik ve kimyasal kalite kriterleri yönünden incelenmesi. VI. Süt ve Süt ürünleri Sempozyumu, 22-23 Mayıs, 547-556, Tekirdağ.

Çakır İ. 2000. Kolliform grup bakteriler ve E.coli, Gıda Mikrobiyolojisi ve Uygulamaları, 2. Bask1, Sim Matbaacılık ve Ltd.Şti, Ankara.

Devlieghere F, Vermeiren L, and Debevere J. 2004. New preservation technologies: possibilities and limitations. International Dairy Journal, 14, 273-285.

Dığrak M, Yılmaz Ö, Çelik S ve Özçelik S. 1996. Elazığ'da satışa sunulan taze beyaz peynirlerin mikrobiyolojik kalitesi ve yağ asitleri analizi. Turkish Journal of Biology, 20, 221-230.

Elmnasser N, Federighi M, Bakhrouf A and Orange N. 2010. Effectiveness of pulsed ultraviolet light treatment for bacterial inactivation on agar surface and liquid medium. Foodborne Pathogens and Disease, 7(11), 1401-1406.

Elmnasser N, Guillou S, Leroi F, Orange N, Bakhrouf A and Federighi M. 2007. Pulsed-light system as a novel food decontamination technology: a review, Canadian Journal of Microbiology, 53, 813-821.

Erkan S. 2017. Elazığ' da satışa sunulan şavak tulum peynirlerinin aflatoksin $\mathrm{m} 1$ (afm1) ve bazı kimyasal parametreler bakımından incelenmesi. Yüksek Lisans Tezi, Fırat Üniversitesi Sağlık Bilimleri Enstitüsü, Elazığ, Türkiye

FAO, 1992. Manual of Food Quality Control. 4. Rev. 1. "Microbiological Analysis". Food and Agricultural Organization of the United Nations, Rome, pp 43-56.

Galvez A, Lucas LR, and Abriouel H. 2008. Application of bacteriocins in the control of foodborne pathogenic and spoilage bacteria. Crit Rev Biotechnol, 28, 125-152.

Gomez-Lopez VM, Devlieghere F, Bonduelle V, Debevere J. 2005. Intense light pulses decontamination of minimally processed vegetables and their shelf-life, International Journal of Food Microbiology, 103, 79-89.

Halkman AK, Noveir MR ve Doğan HB. 2001. Escherichia coli O157: H7 Serotipi, Sim Matbaac1lık Ltd. Şti, Ankara, 43s.

Harrigan WF. 1998. Laboratory Methods in Food Microbiology, 3rd ed, Academic Press, London.

Keklik NM. 2019. Treatment of pastirma with pulsed UV light: Modeling of Staphylococcus aureus inactivation and assessment of quality changes. Food Science and Technology International, 0(0) 1-14

King RL. 1962. Oxidation of milk fat globule membrane material. I. Thiobarbituric acid reactio $n$ as a measure of oxidized flavor in mişkm and membrane systems. Journal of Dairy Science, 45, 1165-1171.

Koçer G. 2017. Atımlı Uv Işık Ve Gümüş Nanopartiküllerinin Beyaz Şapkalı Kültür Mantarı (Agarıcus Bısporus) Yüzeyinde Listerı Monocytogenes'in İnaktivasyonu Üzerine Etkileri. Yüksek Lisans Tezi, Cumhuriyet Üniversitesi Fen Bilimleri Enstitüsü, Sivas, Türkiye.

Krishnamurthy K. 2006. Decontamination of milk and water by pulsed uv-light and infrared heating. Doctoral Thesis, The Pennsylvania State University, The Graduate School Department of Agricultural and Biological Engineering , USA.

Kurt A, Çakmakçı S, Çağlar A. 1991. Erzincan tulum peynirinin yapılışı, duyusal, fiziksel ve kimyasal özellikleri üzerine bir araştırma. Gıda, 16(5), 295-302.
Lasagabaster A, Arboleya JC, I. Martínez de Marañón. 2011. Pulsed light technology for surface decontamination of eggs: impact on Salmonella inactivation and egg quality. Innovative Food Science \& Emerging Technologies, 12: 124128.

Marshall RT. 1992. Standard Methods for the Examination of Dairy Products, 16th ed, APHA 1015, Washington.

Oms-Oliu G, Aguiló-Aguayo I, Martín-Belloso O, and SolivaFortuny R. 2010. Effects of pulsed light treatments on quality and antioxidant properties of fresh-cut mushrooms (Agaricus bisporus), Postharvest Biology and Technology, 56, 216-222.

Parveen R, Kausar R, Sameen A, Khan MI, Sana N. 2016. Effect of activating lacto peroxidase system (LPS) on quality and storage stability of soft cheese. Journal of Biotechnology Biomaterials, 6 (2): Article 224.

Pichhardt K. 2004. Gıda Mikrobiyolojisi. Literatür Yayıncılık, İstanbul.

Rogga KJ, Samelis J, Kakouri A, Katsiari MC, Savvaidis IN and Kontominas MG. 2005. Survival of Listeria monocytogenes in Galotyri, a traditional Greek soft acid-curd cheese, stored aerobically at $4{ }^{\circ} \mathrm{C}$ and $12^{\circ} \mathrm{C}$. Int Dairy J., 15, 59-67.

Ross AIV, Griffiths MW, Mittal GS and Deeth HC. 2003. Combining nonthermal technologies to control foodborne microorganisms. International Journal of Food Microbiology, 89, 125-138.

Rowan NJ, MacGregor SJ, Anderson JG, Fouracre RA, McIlvaney L and Farish O. 1999. Pulsedlight inactivation of food-related microorganisms. Applied and Environmental Microbiology, 65, 1312-1315.

SAS/STAT Software, 1998. Changes and Enhancements through Release 6.12., SAS Institute Inc., Cary, N.C., U.S.A.

Sert S, Kıvanç M. 1984. Erzurum piyasasında taze olarak tüketime sunulan beyaz peynirlerin hijyenik kaliteleri üzerinde bir araştrma. Atatürk Üniversitesi Ziraat Fakültesi Dergisi, 15 (3-4), 79-83.

Statistical Analysis System (SAS): Version 8.0. SAS Institute. Cary, North Caroline, USA, 1999.

Swanson KML, Busta FF, Peterson EH and Johnson MG. 1992. Colony counts method. In: Compendium of methods fort he microbiological examination of foods. 3rd edition. Vanderzant C, Splittstosser DF (Ed.), America Public Health Association. Chapter 16, 239-249. D.C. Washington.

Tan S, Ertürk YE. 2002. Peynir. TAE/Bakış Yayınları, Ankara.

Trujillo AJ, Capellas M, Gervilla R, Saldo J, Guamis B. (2002). Application of high hydrostatic pressure on milk and diary products: a review. Innovative Food Science and Emerging Technologies, 3, 295-307.

Tülek Y, Filizay G. 2006. Gıda endüstrisinde kullanılan yüksek hidrostatik basınç sistemleri. Pamukkale Üniversitesi. Mühendislik Bilimleri Dergisi, 12(2), 225-231.

Türk Gıda Kodeksi Mikrobiyolojik Kriterler Yönetmeliği. T.C. Resmi Gazete, sayı: 28517, 29 Aralık 2011.

Türk Gıda Kodeksi Peynir Tebliği. T.C. Resmi Gazete, sayı: 29261, 8 Şubat 2015 (TEBLİ̆ NO: 2015/6)

Türk Standardları Enstitüsü 1995. Beyaz Peynir, TS 591, TSE, Ankara.

Uğur E. 2018. Çiğ sütten yapılan beyaz peynirde ticari faj preparatlarıyla patojen bakterilerin kontrolü. Yüksek Lisans Tezi, Süleyman Demirel Üniversitesi Fen Bilimleri Enstitüsü , Isparta, Türkiye

Weimer PJ. 2001. Microbiology of the dairy animal. Marth, E.H., Steele, J.L. (Eds), Applied Dairy Micrbiology, Marcel Dekker Inc., 1-59, USA.

Wekhof A. 2000. Disinfection with flash lamps. Journal of Pharmaceutical Science and Technology, 54, 264-276.

Yildırım H. 2014. Geleneksel şavak tulum peynirin olgunlaştırılması esnasında aside adapte ve adapte edilmemiş salmonella'ların yaşamının araştırılması. Yüksek Lisans Tezi, Tunceli Üniversitesi Fen Bilimleri Enstitüsü , Tunceli, Türkiye. 